\title{
What do We Know about Reaction Mechanism? The Electrospray Ionization Mass Spectrometry Approach
}

\author{
Leonardo S. Santos \\ Laboratory of Asymmetric Synthesis and Fraunhofer Chile Research Foundation, \\ Chemistry Institute of Natural Resources, Universidad de Talca, Talca, P.O. Box 747, Chile
}

\begin{abstract}
O fascínio do homem por reações químicas remonta aos tempos antigos. Com a introdução de técnicas espectroscópicas, a arte de explorar as reações se tornou uma ciência intrigante. Portanto, não é surpreendente que uma das fronteiras mais prósperas e gratificantes na Química moderna é o estudo de mecanismo de reações em processos químicos e biológicos. Como a imaginação do homem não termina nas fronteiras definidas pela natureza, e com o poder crescente da catálise, o químico orgânico sintético está pronto para contribuir de uma maneira importante no invento e desenvolvimento de novas tecnologias que permitam a geração de novos catalisadores e metodologias. Neste account uma nova ferramenta para acelerar o desenvolvimento na descoberta de novas reações é revisada através do monitoramento por espectrometria de massa com ionização eletrospray (ESI-MS).
\end{abstract}

Man's fascination with chemical reactions goes back to ancient times. With the introduction of spectroscopic techniques, the art of exploiting reactions became an intriguing science. It is, therefore, not surprising that one of the most flourishing and rewarding frontiers in modern Chemistry is the study of reaction mechanisms in chemical and biological processes. As man's imagination does not stop at the frontiers defined by nature, and with the ever increasing power of catalysis, the synthetic organic chemist is poised to make important contributions by inventing and developing new enabling technologies for the generation of new catalysts and methodologies. In this account is offered a new tool for accelerating the development through electrospray ionizationmass spectrometric (ESI-MS) monitoring in new reaction discovering.

Keywords: reaction mechanism, ESI-MS, online monitoring, microreactor, organometallic complexes

\section{Introduction}

The tremendous growth of mass spectrometry (MS) over the past two decades has been spurred on in part by the desire to determine the matter in attoscale for MS applications to proteins, proteome. Catalyzing this growth have been the spectacular advances in the types of mass spectrometry instrumentation that are being brought to bear on this problem. In addition, new and improved ionization methods have greatly expanded the types of systems that may be studied. Organic chemistry has been paralleled by a similar rapid growth in the area of gas-phase ion chemistry, which the design of more efficient reactions brings together researchers with diverse backgrounds in organic, inorganic, bioinorganic, surface chemistry

*e-mail: 1ssantos@utalca.cl and catalysis. In analogy to the wealth of information pertaining to gas-phase organic ion chemistry, the study of transient ions offers the opportunity to probe the intrinsic chemical and physical properties of these species in the absence of complicating factors such as solvation and ionpairing effects. In addition, the gas-phase results provide benchmarks data to compare with detailed theoretical calculations. The chemistry of these short life species not only is interesting in its own right, but can provide important clues as to mechanisms occurring in condensed phases by yielding a better understanding of key steps and potential intermediates. In the course of discovering all these wonderfully useful techniques, we have learned more about the discovery process itself and have developed an ever expanding set of new discovery tools. The invention of these new platforms for innovation in chemistry reaction mechanism is being powered by dramatic advances in 
technology, computing and the underlying chemical and biomedical science. Even with the considerable progress in organometallic chemistry, there are important gaps in the understanding of mechanistic details through classical organic chemistry, which produce challenges for future research. A major problem with respect to such mechanistic studies comes up from the complexity of transition-metal catalysis in conjunction with nontrivial difficulties to carry out accurate kinetic studies: (i) low steady-state concentration of the reactive intermediates, (ii) presence of aggregates or clusters and (iii) apparently simple, but yet nontrivial experimental difficulties in sampling shortlife and sensitive organometallic compounds. ${ }^{1}$ That is why some dedicated physical-organic chemists do hesitate to go through organometallic chemistry.

In this account, several topics of current interest in the reaction mechanistic studies by electrospray ionizationmass spectrometric (ESI-MS) are highlighted. ${ }^{2}$ Most of the discussion revolves around recent results using powerful methodology based on direct analyses and coupling microreactors to ESI-MS ion-source. Selected work from other laboratories is also included. Since the scope of this paper is necessarily limited, the reader is urged to read comprehensive reviews on the subject. ${ }^{3-6}$ However, a brief comment in the ESI mechanism must be emphasized.

\section{Preservation of the Charge in the Transit of Ions from Solution to the Gas Phase: the ESI-MS Reflects What is being Produced in Solution?}

The electrospray process can be described with relative simplicity. A solution of the analyte is passed through a capillary hold at high potential. The high voltage generates a mist of highly charged droplets which passes through a potential and pressure gradients towards the analyzer portion of the mass spectrometer. During that transition, the droplets reduce their size by evaporation of the solvent and by droplet subdivision resulting from the coulombic repulsions caused by the high charge density achieved in the shrinkage. As final result, the ions become completely desolvated. $^{\text {? }}$

The charge state of the isolated ions is expected to closely reflect the charge state in solution (multiply charged species are sometimes observed due to ion/molecule reactions in the interface), since the transfer of ions to the gas phase is not an energetic process, the desolvation is indeed a process that effectively cools the ion. ${ }^{8-10}$ Therefore, it can be assumed that the ESI involves only the stepwise disruption of non-covalent interactions, principally the removal of molecules of solvation, and interception of this process may allow the preservation of relatively strong non-covalent interactions of analytical significance. ${ }^{9}$ The experimental information available so far on the preservation of the charge is not clarifying. ${ }^{10}$ Single-electron transfer can occur during the electrospray process, because the ESI capillary may act as an electrolytic half-cell when extreme conditions are employed. ${ }^{11}$ Some neutral organic molecules that posse no sites of protonation/deprotonation have also been analyzed using unconventional conditions for ESI technique. ${ }^{12}$ In all these examples, high ion-source voltages or modifications in the configuration of equipments were carried out to achieve the electrolytic-cell like ESI-MS.

All these cases suggest the necessity to perform a rigorous analysis to probe unambiguously that the species detected by ESI are the ones prevailing in solution, and more importantly to confirm that they are indeed reactive intermediates on the reaction path. An outstanding methodology is to isolate in the gas phase the species assumed to participate in the reaction mechanism and perform ion/molecule reactions with the substrate of the reaction solution that will be discussed below. This methodology is very powerful to discard side-products and to assure the reliability of the analysis. Another important method is the study of well-known reactions and compares the data obtained by ESI-MS with other spectroscopic techniques.

\section{Monitoring Methods}

There are two different possibilities for study a reaction using API (atmospheric pressure ionization) methods, i.e. offline and online screenings. Early investigations using API techniques were usually performed offline. ${ }^{13,14} \mathrm{~A}$ sequence of events in offline study of a reaction in solution by mass spectrometry could be: $(i)$ investigate the specific reaction conditions by mixing the reagents for the detection of the different intermediates and (ii) and then determine the solution composition over time when the reactants are progressively transformed into products..$^{15,16}$ This latest operation can be accomplished by direct screening by MS of the reaction intermediates during pre-defined intervals and characterization by MS/MS, always if there is a reasonable concentration of them in solution, and these species are not degraded within few seconds/minutes. The overall time resolution has to match the rate of the process to yield the desired information. However, there are some inherent limitations to this approach (offline monitoring). Transient species can not be therefore analyzed with this feature due to their short lifetime residence in solution.

In a second scenario, the kinetic and mechanistic informations about the reactions in solution can be studied 
using reactors coupled to the ion-source. The first online mass spectrometric investigation in electrochemical reactions using thermospray ionization was reported in 1986. ${ }^{17}$ Another example of online investigations is the reaction of ferric bleomycin and iodosylbenzene that was given by Sam and co-workers ${ }^{18}$ in 1995, a low dead volume mixing tee directly attached to the spray source was used. This feature provides mass-specific characterization of stable products and reactive intermediates with lifetimes down to the millisecond time regime, and subtle changes in the reactional medium can also be observed. The simplest reactor online coupled to the mass spectrometer is the own syringe. It allows screening the reaction in real time, and trapping of transient species. Several groups developed different devices to study the mechanism in solution of radical initiated, photochemical, electrochemical and organometallic reactions, reducing the transit time of the species during the experiments. ${ }^{3}$

\section{Reaction Mechanism Studies}

Relative few examples of radical-monitoring reactions have appeared in the literature. ${ }^{19,20}$ Thus, structural investigation of a novel heterogeneous Fenton system based on a $\mathrm{FeO} / \mathrm{Fe}_{3} \mathrm{O}_{4}$ composite and $\mathrm{H}_{2} \mathrm{O}_{2}$ was studied by us (Scheme 1). ${ }^{21}$ Online ESI-MS and ESI-MS/MS show that model aromatic compounds (phenol, benzene and chlorobenzene) are successively oxidized to phenolic, benzoquinonic and ring open carboxylic acid-type intermediates. The ESI(-)-MS interception of the anionic poly-hydroxylated intermediates indicates degradation via the successive attack by $\mathrm{HO}^{\bullet}$ radicals formed likely from reactions of $\mathrm{H}_{2} \mathrm{O}_{2}$ with $\mathrm{Fe}^{2+}$ species.

Dalmazio et al. ${ }^{22}$ reported in an interesting article the mechanism of degradation of caffeine by $\mathrm{TiO}_{2} / \mathrm{UV}, \mathrm{H}_{2} \mathrm{O}_{2} / \mathrm{UV}$ and Fenton systems (Scheme 2). The continuous online and real-time monitoring, by electrospray ionization mass (ESI-MS) and tandem mass spectrometric experiments (ESI-MS/MS) as well as high accuracy MS measurements, shows that caffeine is first oxidized to $N$-dimethylparabanic acid likely via initial $\mathrm{OH}$ insertion to the $\mathrm{C} 4-\mathrm{C} 8$ caffeine double bond. A second degradation intermediate, di( $N$-hidroxymethyl)parabanic acid, has been identified by ESI-MS and characterized by ESI-MS/MS and high accuracy mass measurements (with errors around of 5-7 ppm). This polar and likely relatively unstable compound, which is not detected by other techniques, is suggested to be formed via further oxidation of $\mathrm{N}$-dimethylparabanic acid at both of its $N$-methyl groups and constitutes an unprecedented intermediate in the degradation of caffeine.

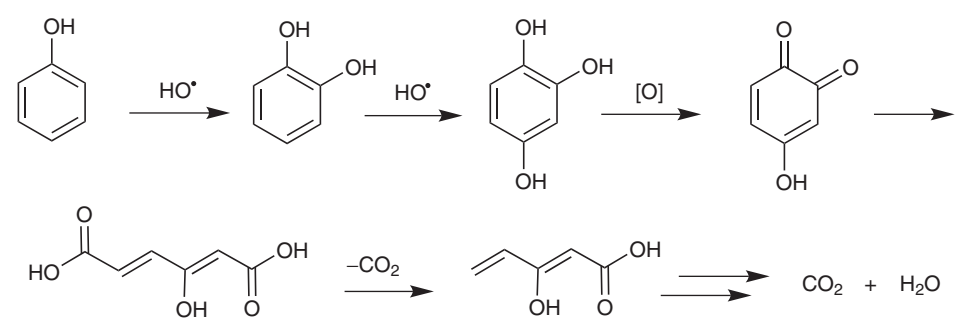

Scheme 1. ESI-MS monitoring of phenol degradation through heterogeneous Fenton system.
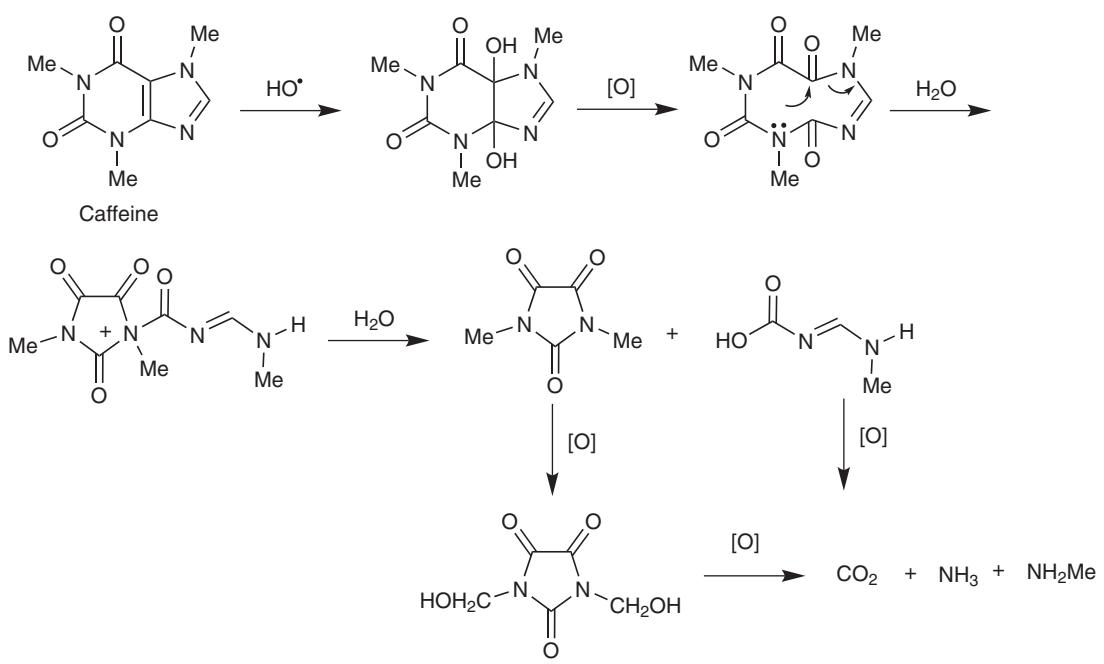

Scheme 2. Mechanism of degradation of caffeine by ESI-MS on-line monitoring through $\mathrm{TiO}_{2} / \mathrm{UV}, \mathrm{H}_{2} \mathrm{O}_{2} / \mathrm{UV}$ or Fenton systems. 


\subsection{Mimicking atmospheric oxidation of isoprene}

Photo-oxidation of isoprene in the atmosphere was thought to yield only lighter and more volatile products such as formaldehyde, methacrolein and methyl vinyl ketone. Evidence for the formation of hygroscopic polar products, such as 2-methyl-1,2,3,4-tetrahydroxybutane, that can give rise to aerosols by gas-to-particle formation processes opened a new and wide-range panorama for the isoprene role in the atmosphere. Under simulated atmospheric conditions, photo-oxidation of isoprene by ozone was shown to be relatively slow and to occur mainly via reaction with $\mathrm{OH}$ radicals. Furthermore, when the $\mathrm{OH}$ radical-initiated photo-oxidation of isoprene was performed in the absence of $\mathrm{NO}_{x}, 1,2$-diol derivatives were formed supporting the "C $\mathrm{C}_{5}$ isoprene hypothesis" 23 for the formation of the secondary organic aerosol (SOA) marker compounds. ${ }^{24}$

\subsection{The Baylis-Hillman reaction}

In a representative example of online monitoring the Baylis-Hillman reaction was studied by ESI-MS in both the positive and negative ion modes. The reactions were performed in a sealed syringe as the reactional medium directly coupled to ion-source. ${ }^{25}$ The proposed intermediates for the catalytic cycle of the reaction (Scheme 3) were successfully intercepted and structurally characterized for the first time using ESI-MS and MS/ MS. Strong evidence was collected corroborating the currently accepted mechanism. ${ }^{26}$ In a similar manner, online monitoring of Baylis-Hillman reactions co-catalyzed by ionic liquids achieved the gas phase supramolecular species responsible for the co-catalytic role of ionic liquids in the reaction. ${ }^{27}$ Via competitive experiments, it was found that the order of $\mathrm{BH}$ co-catalysis efficiency employing three ionic liquids was: $\mathrm{BMI} \cdot \mathrm{CF}_{3} \mathrm{CO}_{2}>\mathrm{BMI} \cdot \mathrm{BF}_{4}>>\mathrm{BMI} \cdot \mathrm{PF}_{6}$, which was the opposite to that observed by in the liquid phase. Based on the interception of those unprecedented supramolecular species, it was proposed that the role of 1,3-dialkylimidazolium ionic liquids as co-catalysts for the $\mathrm{BH}$ reaction was by activating the aldehyde toward nucleophilic attack via $\mathrm{BMI}^{+}$coordination, and/or by stabilizing the zwitterionic species that acted as the main $\mathrm{BH}$ intermediates through supramolecular coordination.

\subsection{Ring contraction reaction}

Looking for experimental support to validate the mechanism of ring contraction as proposed by Ferraz et al..$^{28}$ for the reaction depicted in Scheme 4, online monitoring of the reaction by ESI-MS and ESI-MS/MS using the own syringe as the reactional medium was performed by us. A bicyclic iminium ion intermediate was proposed to participate in the reaction (Scheme 5), but both reactant and product were neutral molecules. These neutral species were, however, expected to be in equilibrium in solutions of protic solvents such as methanol with their protonated forms. Therefore, ESI could transfer both reactants and products
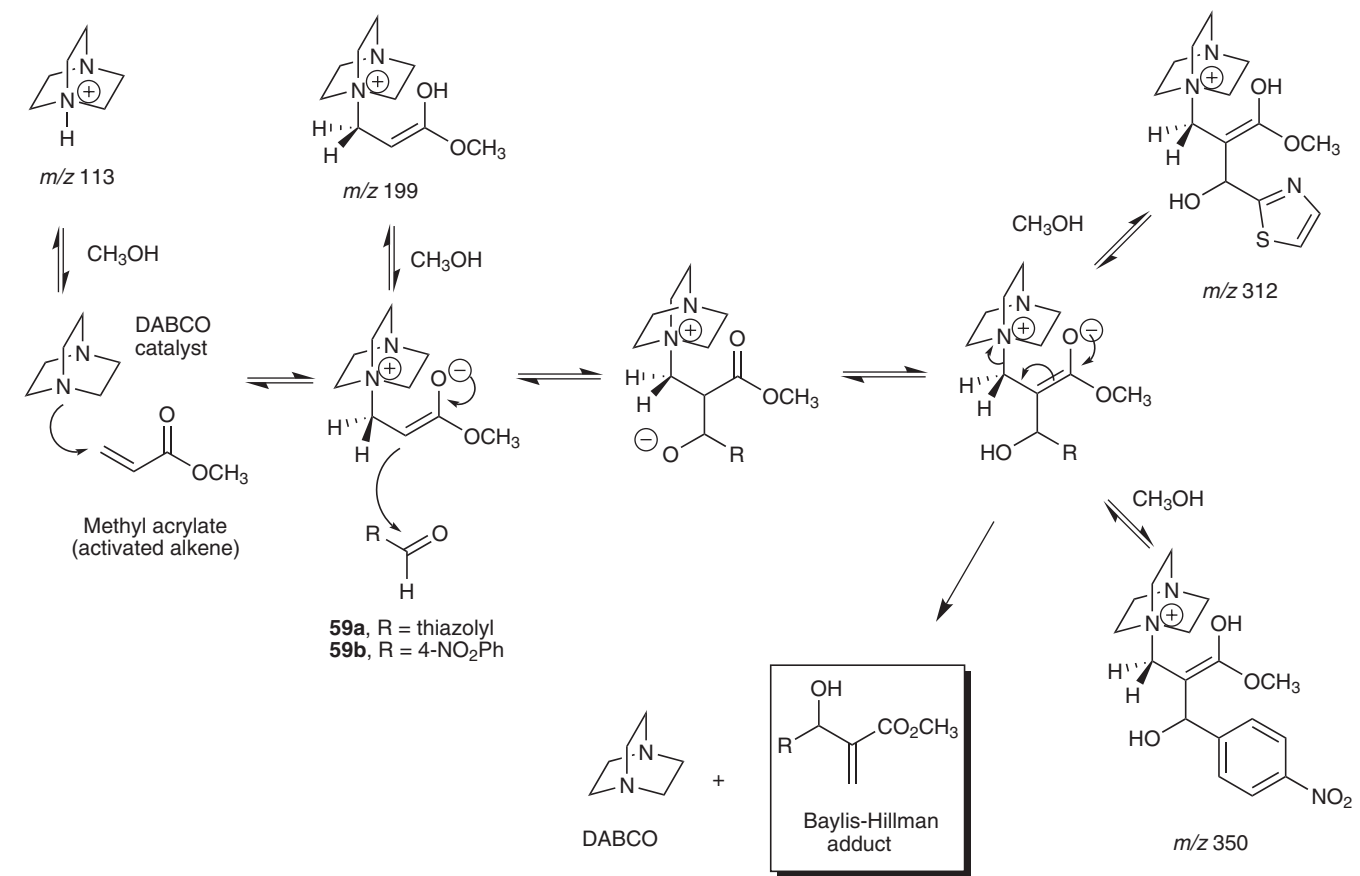

$m / z 350$

Scheme 3. Mechanism of Baylis-Hillman reaction of methyl acrylate and aldehydes catalyzed by DABCO. The protonated species expected to be intercepted and structurally characterized by $\mathrm{ESI}(+)$-MS/MS and their respective $\mathrm{m} / \mathrm{z}$ ratios. 
<smiles>CCOC(=O)C1=C(C)N(P)C(CI)CC1</smiles>

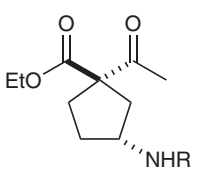

$\mathrm{R}=\mathrm{Ph}, 72 \mathrm{~h}, 73 \%$ $\mathrm{R}=\mathrm{Bn}, 24 \mathrm{~h}, 85 \%$ $\mathrm{R}=p-\mathrm{MeOPh}, 72 \mathrm{~h}, 77 \%$

Scheme 4. Ring contraction reaction.

to the gas phase as $[\mathrm{M}+\mathrm{H}]^{+}$species for MS analysis. Scheme 5 summarizes a general reaction pathway showing neutral and protonated reactants and protonated products, as well as the key bicyclic iminium ion intermediates that have been intercepted and structurally characterized by ESI(+)-MS(/MS).

\subsection{The Meisenheimer complex}

Another interesting approach using ESI(-)-MS was used to probe the mechanism of nucleophilic substitution reactions of methylated hydroxylamines, hydrazine and hydrogen peroxide with bis(2,4-dinitrophenyl) phosphate (BDNPP).$^{29}$ ESI-MS screening of the reaction was performed to fish for the first time a transient cyclic Meisenheimer complex (Figure 1).

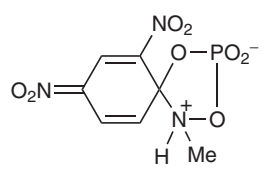

Figure 1. Identification and characterization of Meisenheimer complex in the mechanism for the reaction of $\mathrm{MeNHOH}$ and bis(2,4-dinitrophenyl) phosphate probed by ESI(+)-MS experiments, which corroborated kinetics studies.

\section{5. $\alpha$-Methylenation of ketoesters}

Extensive studies have been done to optimize the synthesis of $\alpha$-methylene carbonyl compounds. These are not only useful as synthetic intermediates but may also mimic biologically active natural products compounds and be used as potential antitumor drugs. We investigated via ESI(+)-MS monitoring the reaction of ketoesters with $p$-formaldehyde catalyzed by morpholine in acetic acid:acetonitrile solution (Scheme 6).$^{30}$ As the key players of the catalytic cycle of the reaction could be either ionic or neutral species, the neutral species were intercept as protonated molecules from the acetic acid solutions. Few examples of disfavored proton-transfer equilibrium are described, however, it could be useful in intercepting neutral species because of the high sensitivity of ESI-MS in transferring ionic intermediates from solution to the gas phase. Marquez et al. ${ }^{31}$ and Zhang and $\mathrm{Guo}^{32}$ showed a similar approach for $L$-proline catalyzed reactions.

\subsection{Organometallic catalyzed reactions}

\subsubsection{Palladium-catalyzed reactions}

Roglans and co-workers ${ }^{33,34}$ studied the Heck reaction of arene diazonium salts using a palladium( 0 ) complexes of 15-membered macrocyclic triolefines. The Heck arylation with arenediazonium salts was also studied by Eberlin and co-workers ${ }^{35}$ through ESI-MS and MS/MS mass spectrometry experiments. The group detected and structurally characterized the main cationic intermediates of this catalytic cycle directly from solution. ${ }^{35}$ They proposed a detailed catalytic cycle of the Heck reaction with arene<smiles>CCOC(O)=C1CCC(CI)[NH+]([B]C(C)C)C1C</smiles><smiles>CCOC(O)=C1CCC(CI)N=C1C</smiles>

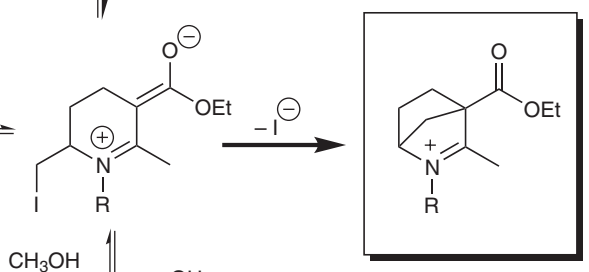<smiles>CCOC(=O)C1(CC)CC[C@@H](N)C1</smiles>
$\mathrm{Ph}$<smiles>CCOC(O)=C1CCC(CI)N(CC)C1C</smiles>

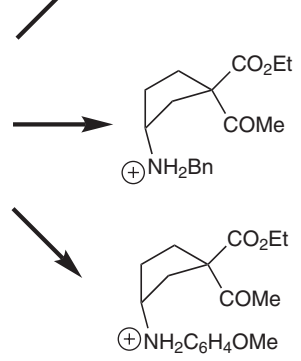

Scheme 5. Mechanism probed by ESI-MS for ring contraction reaction of iodo- $\beta$-enamino-esters. The screening was performed using Et ${ }_{3} \mathrm{~N}$ in toluene/methanol (1:1). 


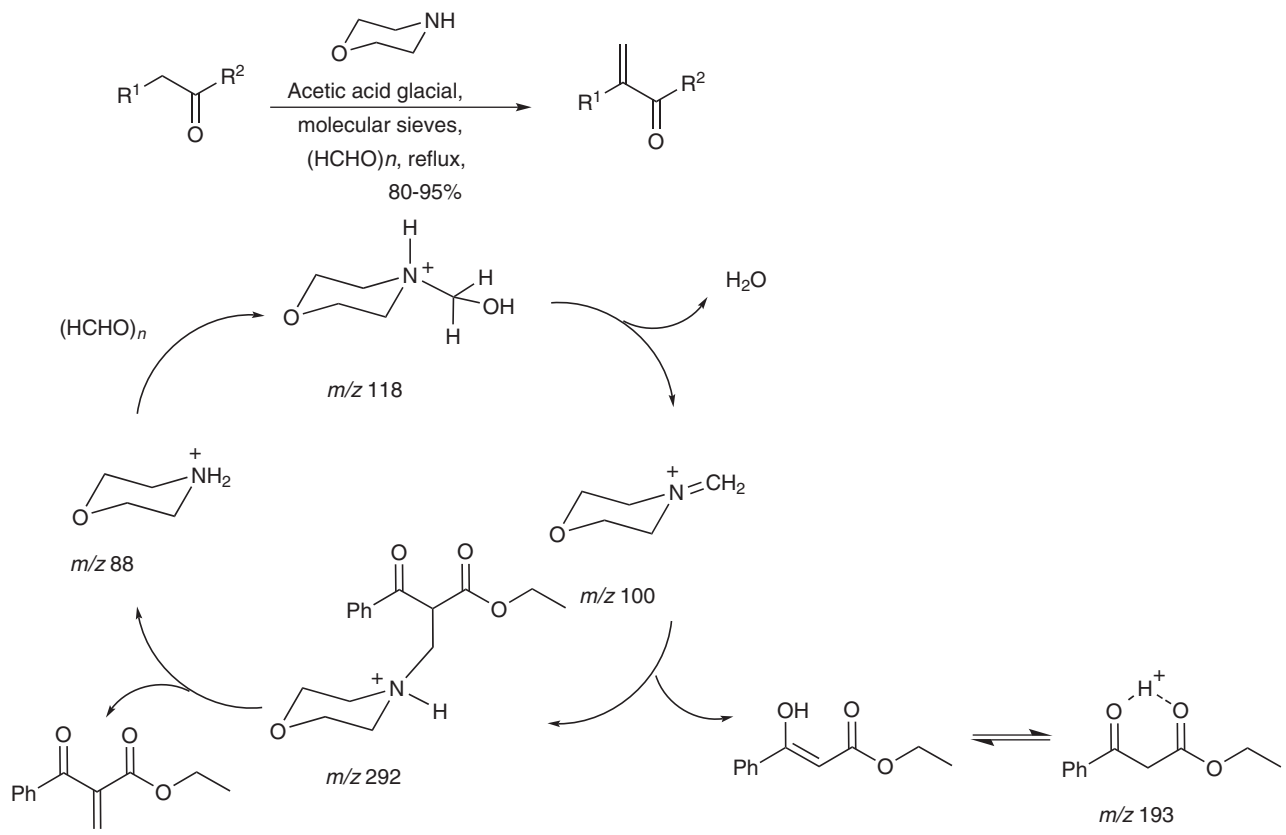

Scheme 6. Direct Mannich-type $\alpha$-methylenation of carbonyl compounds.

diazonium salts on the basis of the results obtained from ESI experiments using 2,3-dihydrofuran as example.

Another Pd-catalyzed reaction, the Suzuki coupling of pyridyl halides with phenylboronic acids, was studied by Aliprantis and Canary ${ }^{15}$ (Scheme 7). They performed offline ESI-MS investigation, identifying pyridylpalladium(II) complexes as the cationic species $\left[(\mathrm{pyrH}) \mathrm{Pd}\left(\mathrm{PPh}_{3}\right)_{2} \mathrm{Br}\right]^{+}(\mathbf{a})$ and $\left[(\mathrm{pyr}) \mathrm{Pd}\left(\mathrm{PPh}_{3}\right)_{2}\right]^{+}(\mathbf{b})$. Additionally, diaryl-Pd(II) $\left[(\mathrm{pyrH})\left(\mathrm{R}^{1} \mathrm{R}^{2} \mathrm{C}_{6} \mathrm{H}_{3}\right) \mathrm{Pd}\left(\mathrm{PPh}_{3}\right)_{2}\right]^{+}$and aryl-Pd(II) $\left[\left(\mathrm{R}^{1} \mathrm{R}^{2} \mathrm{C}_{6} \mathrm{H}_{3}\right)\right.$ $\left.\mathrm{Pd}\left(\mathrm{PPh}_{3}\right)_{2}\right]^{+}$were observed in the ESI mass spectra. Few years later, some new results were published by Roglans and co-workers ${ }^{36}$ on ESI-MS investigation of Pd-catalyzed self-coupling reaction of areneboronic acids. ${ }^{16}$

It is worth to mention that Markert and Pfaltz ${ }^{37}$ applied a creative ESI-MS technique for parallel screening of
Pd-catalyzed enantioselective allylation reaction of diethyl ethyl malonate with allylic esters. Enantiodiscrimination of a palladium catalyst with different chiral ligands was studied by ESI-MS. In the catalytic cycle proposed (Scheme 8), the first step (the formation of Pd-allyl complexes $\mathbf{A}$ and $\mathbf{B}$ ) is fast while the second step (nucleophilic addition to the allylic system to give $(S)$ - and $(R)$-products) is slower. The group proposed that the technique might be used with unlimited number of catalysts in the simultaneous screening, as long as the signals do not overlap. Furthermore, Roglans and co-workers ${ }^{38}$ also studied the substitution of allyl acetate by acetylacetone in presence and absence of Pd catalyst by ESI-MS. However, in these ESI-MS studies revealed that in the allylic substitution, the formation of palladium acetylacetonate complexes rather that the

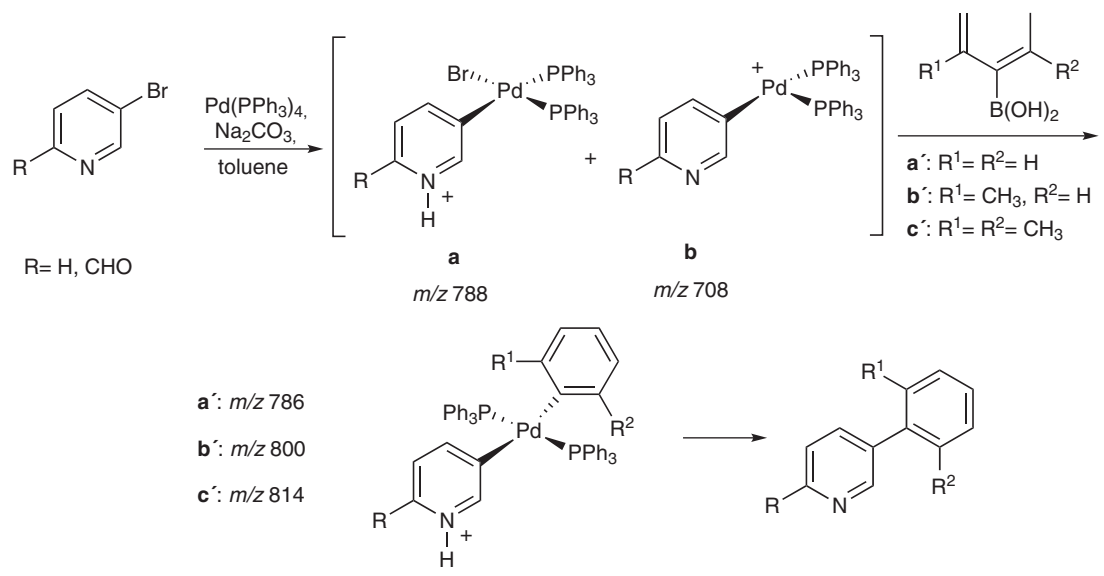

Scheme 7. Pd-catalyzed reaction of pyridyl halides with phenylboronic acids a'-c' after dilution with MeOH for analysis. 

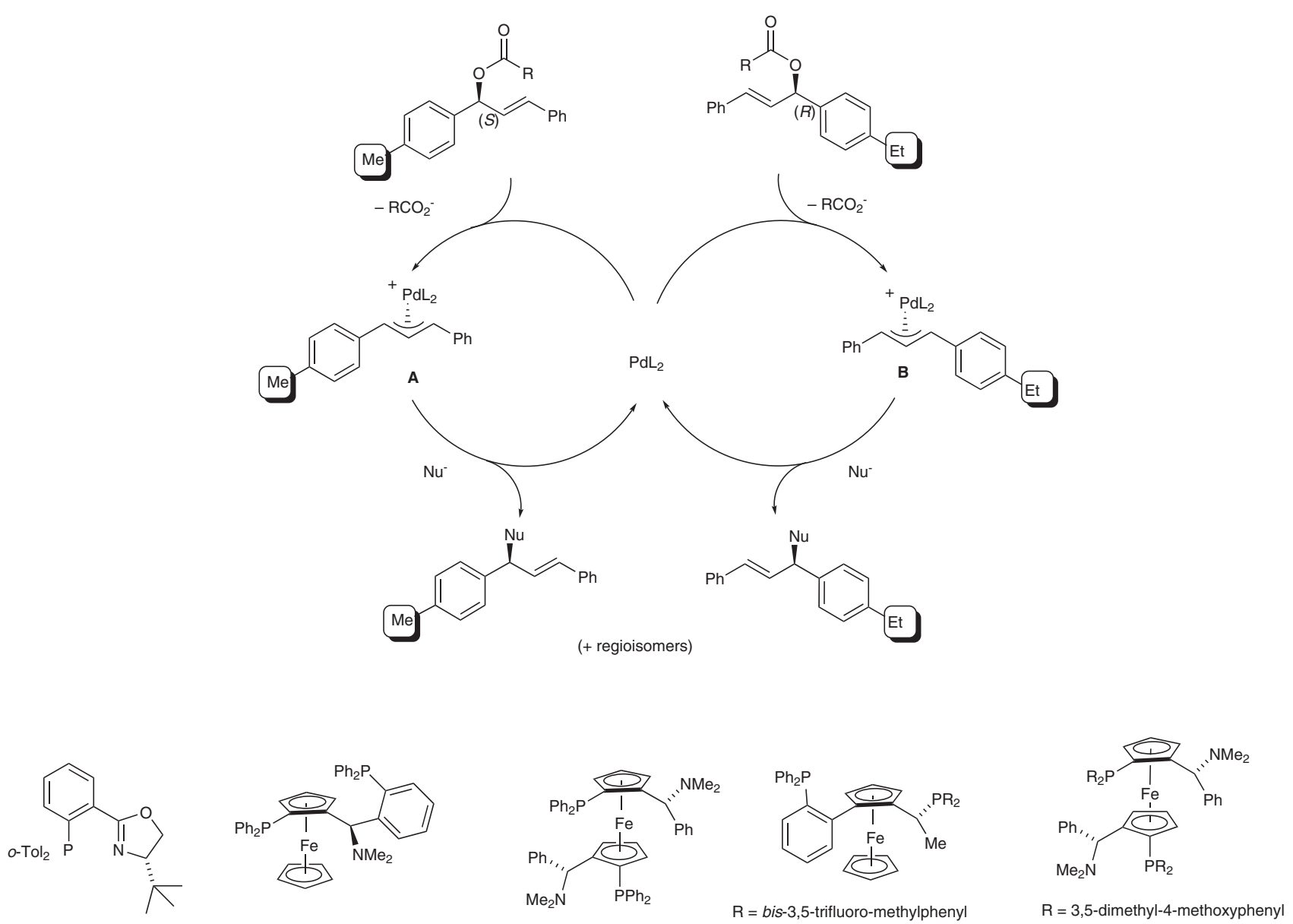

Scheme 8. Simultaneous screening of a mixture of five Pd catalysts performed by Pfaltz.

typically postulated $\pi$-allylpalladium intermediate of type A/B were the key intermediate observed.

\subsubsection{Stille reaction}

For a Stille reaction, online $\operatorname{ESI}(+)-\mathrm{MS}(/ \mathrm{MS})$ monitoring have allowed us ${ }^{39}$ to intercept and characterize: (i) the actual catalytically active species $\mathrm{Pd}^{0}\left(\mathrm{PPh}_{3}\right)_{2}$, (ii) the oxidative addition product and (iii) the transmetalation intermediate and the product of this process (Scheme 9). Therefore for the first time, most (if not all) major intermediates of a Stille reaction have been intercepted, isolated and characterized. Using ESI(-)-MS, the counter anion $\mathrm{I}^{-}$was the single species detected.

Under palladium dichloride catalysis, vinylic tellurides couple efficiently with alkynes with retention of the double-bond geometry. Looking for experimental support to validate the catalytic cycle proposed for this reaction, Comasseto and co-workers ${ }^{40}$ decided to investigate the coupling reaction of vinylic tellurides with alkynes promoted by $\mathrm{PdCl}_{2}$. It was applied ESI to "fish" $\mathrm{Pd}$ - and Te-containing cationic intermediates involved in the reaction described in Scheme 10 directly from the reaction medium to the gas phase for ESI-MS and ESI-MS/MS analysis. The most relevant data for the validation of the proposed catalytic cycle was the detection of three Te and Pd-containing cationic complexes of $m / z, 717,499$ and 627. Ions of $\mathrm{m} / \mathrm{z} 717$ and 499 were suggested to be formed by solution ionization of the neutral species $\mathrm{L}_{\mathrm{n}} \mathrm{PdCl}_{2}$ : that is, $\mathrm{L}_{\mathrm{n}} \mathrm{PdCl}_{2} \rightarrow \mathrm{L}_{\mathrm{n}} \mathrm{PdCl}^{+}+\mathrm{Cl}^{-}$, which have been suggested by $\mathrm{NMR}$ and cyclic voltammetry in reactions where $\mathrm{ArPd}^{+}$ complexes were proposed to participate. ${ }^{15,36}$ An expanded catalytic cycle for the coupling of vinylic tellurides with alkynes catalyzed by palladium dichloride was proposed as depicted in Scheme 11.

\subsection{3. $\mathrm{TeCl}_{4}$ addition to ropargyl alcohols}

$\mathrm{TeCl}_{4}$ is found to display reactivity towards alkynes similar to that of $p$-methoxyphenyltellurium trichloride whereas it reacts with aromatic and 3-hydroxy alkynes by different mechanisms as shown by characteristic stereochemistries of the products. The complete anti stereospecificity of the additions of $\mathrm{TeCl}_{4}$ to all propargyl alcohols studied is consistent with a cyclic chelated telluronium ion intermediate in this reaction. We have 

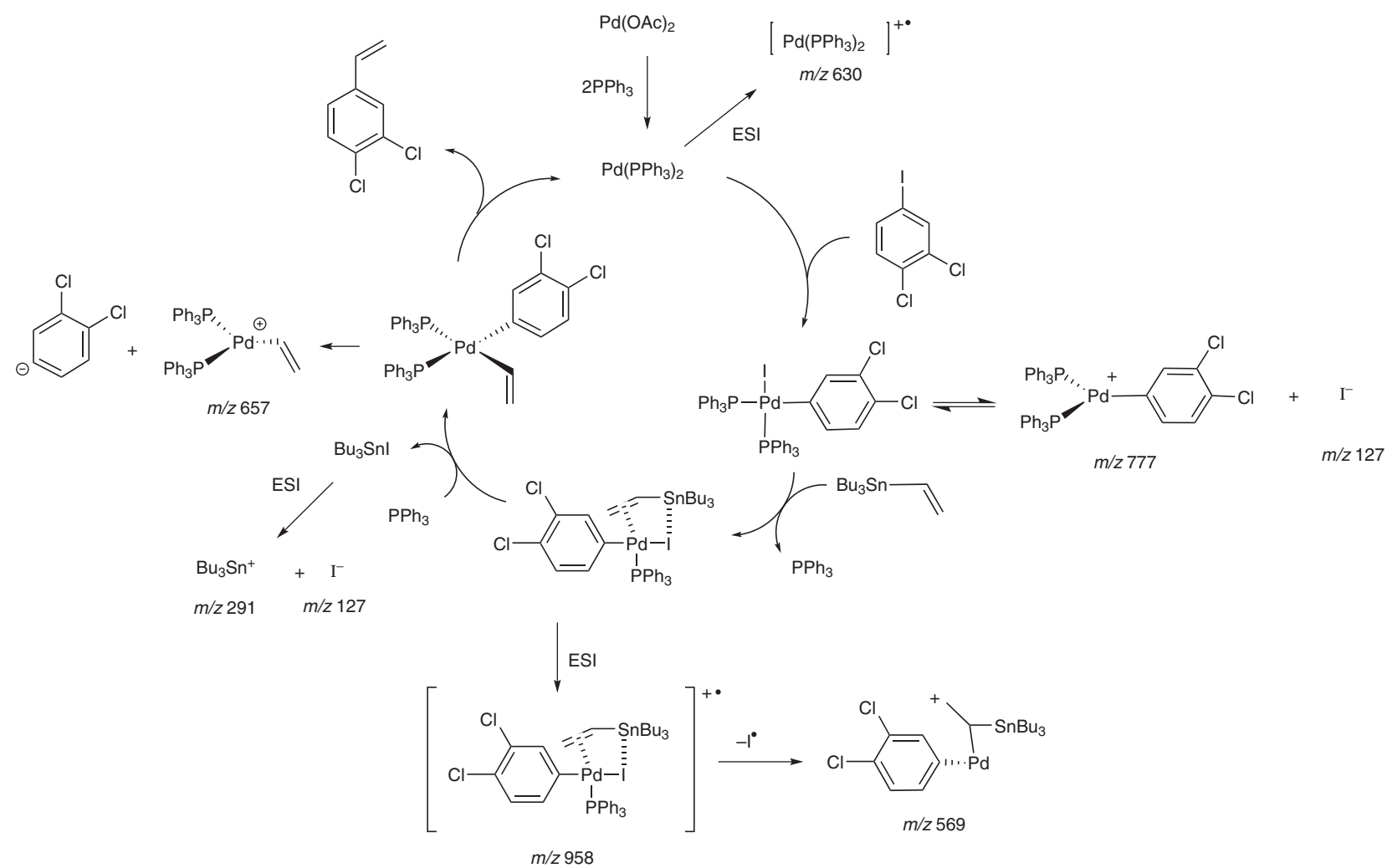

Scheme 9. Expanded mechanism based on ESI(+)-MS data for the Stille reaction of 3,4-dichloroiodobenzene and vinyltributyltin in acetonitrile mediated by $\operatorname{Pd}(\mathrm{OAc})_{2}$.

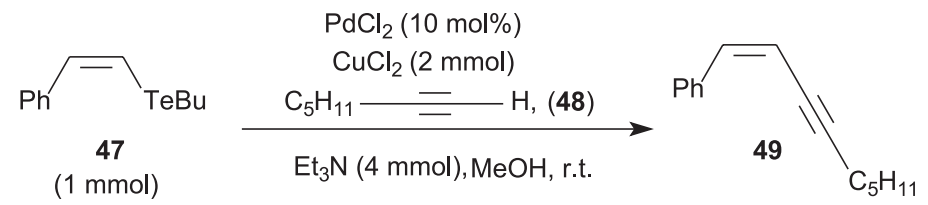

Scheme 10. Coupling of vinylic tellurides with alkynes catalyzed by $\mathrm{PdCl}_{2}$ and $\mathrm{CuCl}_{2}$.

been able to intercept and characterize the active electrophile $\mathrm{TeCl}_{3}{ }^{+}$in THF solution of $\mathrm{TeCl}_{4}$, as well as its THF complex and several $\mathrm{TeCl}_{x}(\mathrm{OH})_{y}{ }^{+}$derivatives. ${ }^{41}$ For the first time also, online ESI-MS(/MS) monitoring permitted key $\mathrm{Te}(\mathrm{IV})$ cationic intermediates of the electrophilic addition of $\mathrm{TeCl}_{4}$ to alkynes to be captured from the solution and to be gently and directly transferred to the gas phase for mass measurement, determination of isotopic patterns, and structural investigation via collision-induced dissociation (Scheme 12). To date, despite their chemical and biological interest, only a few tellurium compounds have been investigated by mass spectrometry. ${ }^{42}$

\section{Probing Reactivity of Intermediates}

We and others introduced an important methodology based on the isolation of species in the gas phase assumed to participate in the reaction mechanism and perform ion/molecule reactions with neutral substrates (in the collision-cell) of the reaction solution. This methodology seems to be very useful to discard side-products and to assure the reliability of the analyses.

Initially, the traditional method used for gas phase ion/molecule reactions were limited to neutral compounds that were sufficiently volatile and thermo-stable to be transferred to the gas phase by heating. Some years ago it was shown that using API conditions (ESI or APCI) the range of neutral molecules participating in ion/molecule reactions could be expanded toward those of lower volatility and thermal stability. ${ }^{43}$

Today this new approach is used by few mass spectrometrists through a great refinement that exploits the outstanding speed, sensitivity and selectivity of the diverse environments that only mass spectrometry offers. The rational relationship between structure and chemical 


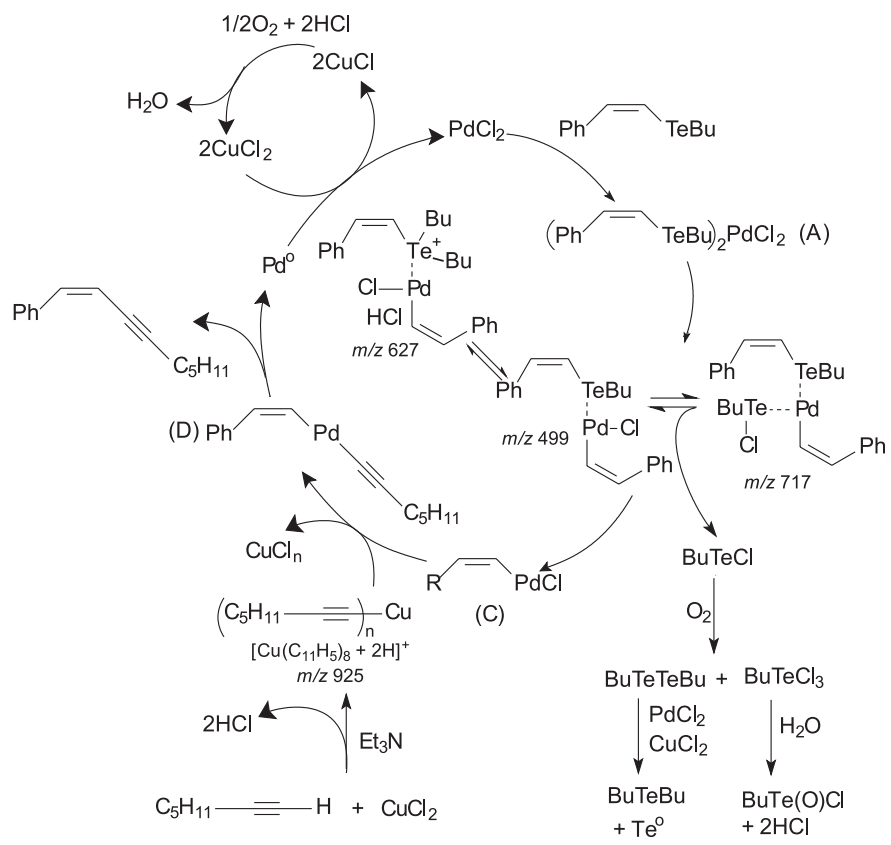

Scheme 11. Expanded mechanism based on ESI(+)-MS tandem MS/MS experiments for the reaction of vinyltelluride with alkyne to give ene-ine compounds by using $\mathrm{PdCl}_{2}$ and $\mathrm{CuCl}_{2}$ in the absence of an inert atmosphere.

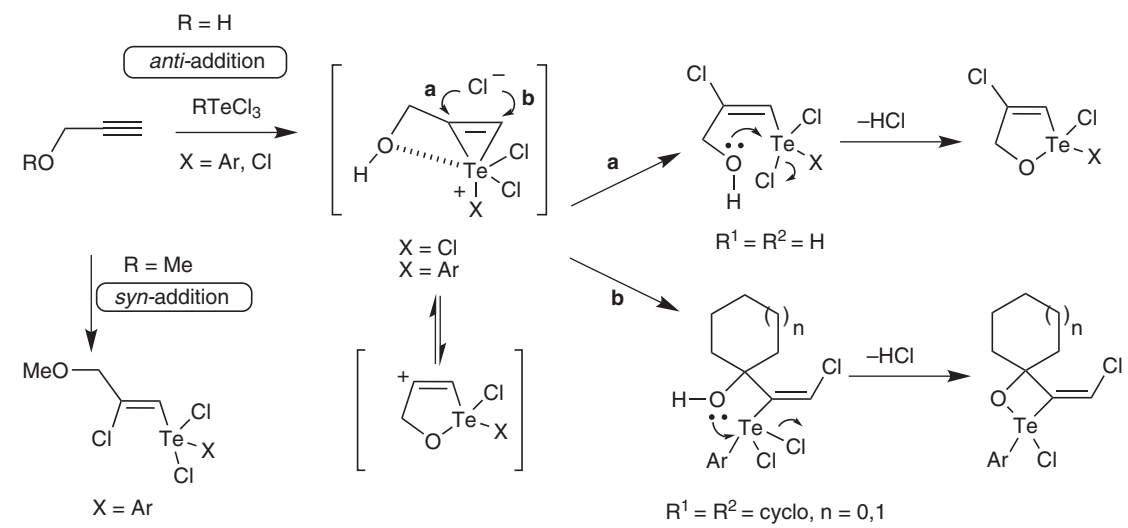

Scheme 12. Propose mechanism of $\mathrm{TeCl}_{4}$ addition to propargyl alcohols.

reactivity are used to investigate the structure of gaseous neutral molecules and ions through several selective ion/molecule reactions. These investigations, which have been reviewed mainly by EI (electron ionization) perspective, ${ }^{44}$ cover the intrinsic mechanistic details of these reactions that occur under the unique solvent- and counter ion-free environments of mass spectrometers. Today, the effectiveness of ion/molecule reactions is employed to probe complex problems in organometallic chemistry. On the other hand, there are few examples of relevance using this approach, with a focus on those reactions performed under the well-defined conditions of sequential mass spectrometry using mass-selected ions.

From a synthetic point of view, mass spectrometrists use to further refined mechanistic studies "triple-quadrupoles" as an useful tool (Figure 2). Triple-quadrupoles, Q-traps, and other devices certainly afford one of the most complete laboratories for the studies of gas phase ion/molecule reactions. The remarkable success of this concept inspired many groups to devote more interest in this potentially advantageous strategy. Thus, using "triple-quadrupoles", ions can be obtained from the ion-source (ESI), purified via mass-selection in Q1, reacted in q2 (collision-cell) under controlled conditions, and further mass analysis of the reaction products performed in Q3. A "triple-quadrupole" like equipment that can be used in this kind of studies is depicted in Figure 2. The main advantage is that all these steps are carried out "online" in very short time intervals, and under conditions that can be maintained for long periods, and that can be easily described and reproduced in different equipments. Another important method is the study of well-known reactions and compares 


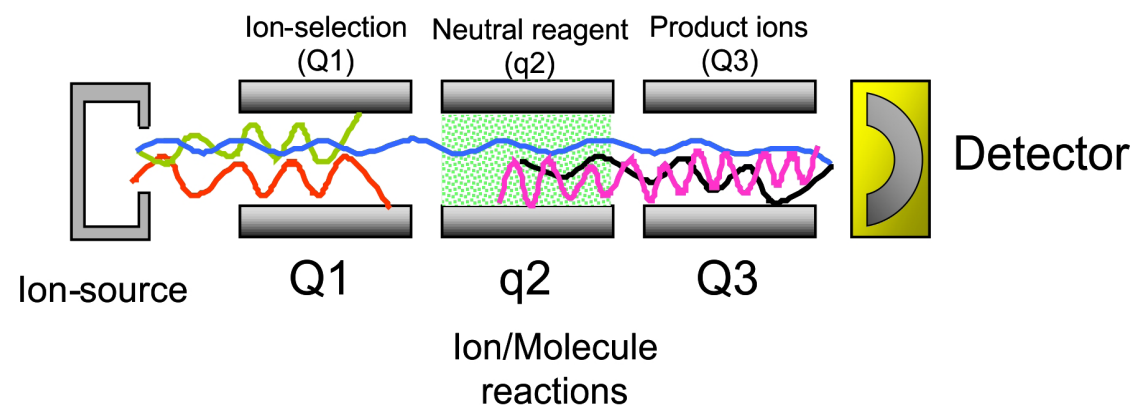

Figure 2. Representative "triple-quadrupole" equipment that is used to study reaction mechanism and further ion/molecule reactions to probe reactivities of trapped species from solutions.

the data obtained by ESI-MS with other spectroscopic techniques.

\subsection{Online screening of Ziegler-Natta polymerization reaction}

Significant remarkable mechanistic investigation has been performed on Ziegler-Natta polymerization reaction. Several mechanistic and kinetic studies led to the general accepted reaction mechanism of ZieglerNatta polymerization, which is depicted in Scheme 13. It is seen that treatment of toluene solution of $\mathrm{Cp}_{2} \mathrm{ZrCl}_{2}$ with MAO (methylaluminoxane) undergoes a rapid initial ligand exchange reaction that firstly generates the monomethyl complex $\mathrm{Cp}_{2} \mathrm{ZrCH}_{3} \mathrm{Cl}$ (2). ${ }^{45}$ Based on solidstate $\mathrm{XPS}^{46}$ and ${ }^{13} \mathrm{C} \mathrm{NMR}{ }^{47}$ studies, as well as ${ }^{91} \mathrm{Zr}$ and ${ }^{13} \mathrm{C}$ NMR investigations of $\mathrm{Cp}_{2} \mathrm{Zr}\left(\mathrm{CH}_{3}\right)$ / $\mathrm{MAO}$ solutions, it was shown that MAO excess leads to $\mathrm{Cp}_{2} \mathrm{ZrMe}_{2}(\mathbf{4})$ and the catalytically active ion-paired species $\left[\mathrm{Cp}_{2} \mathrm{ZrCH}_{3}\right]^{+}(\mathbf{5})$ with the counter ion $\left[\mathrm{X}-\mathrm{Al}(\mathrm{Me}) \mathrm{O}^{-}\right]_{n}^{-}(\mathrm{X}=\mathrm{Cl}, \mathrm{Me}) .{ }^{45}$ The cation $\mathrm{Cp}_{2} \mathrm{ZrCH}_{3}{ }^{+}(\mathbf{5})$ in the presence of ethene gives via $\pi$-complex $(6)$ the insertion product $(7)(n=1)$ as the first intermediate of the polymerization process, which is followed by step-by-step insertion of ethene achieving the cationic alkyl zirconocenes $(7)(n=2,3 \ldots n) . \beta$-Elimination gives the uneven chain polymer containing a terminal $\mathrm{C}-\mathrm{C}$ double bond (8) and cationic zirconocene hydride (9), which is able to start polymerization to give via zirconocene cation the even chain polymer (10). Despite its remarkable interest in the polymer field, we ${ }^{48}$ demonstrated that cation $\mathrm{Cp}_{2} \mathrm{ZrCH}_{3}{ }^{+}$was easily detected in the reaction solution of $\mathrm{Cp}_{2} \mathrm{ZrCl}_{2}$ and MAO by ESI-MS, it was characterized by MS/MS and the catalytic activity was directly demonstrated by ion/molecule reaction with ethene in the gas phase. Furthermore, for the first time, using a microreactor online coupled to the ESI source (Figure 3), it was possible to

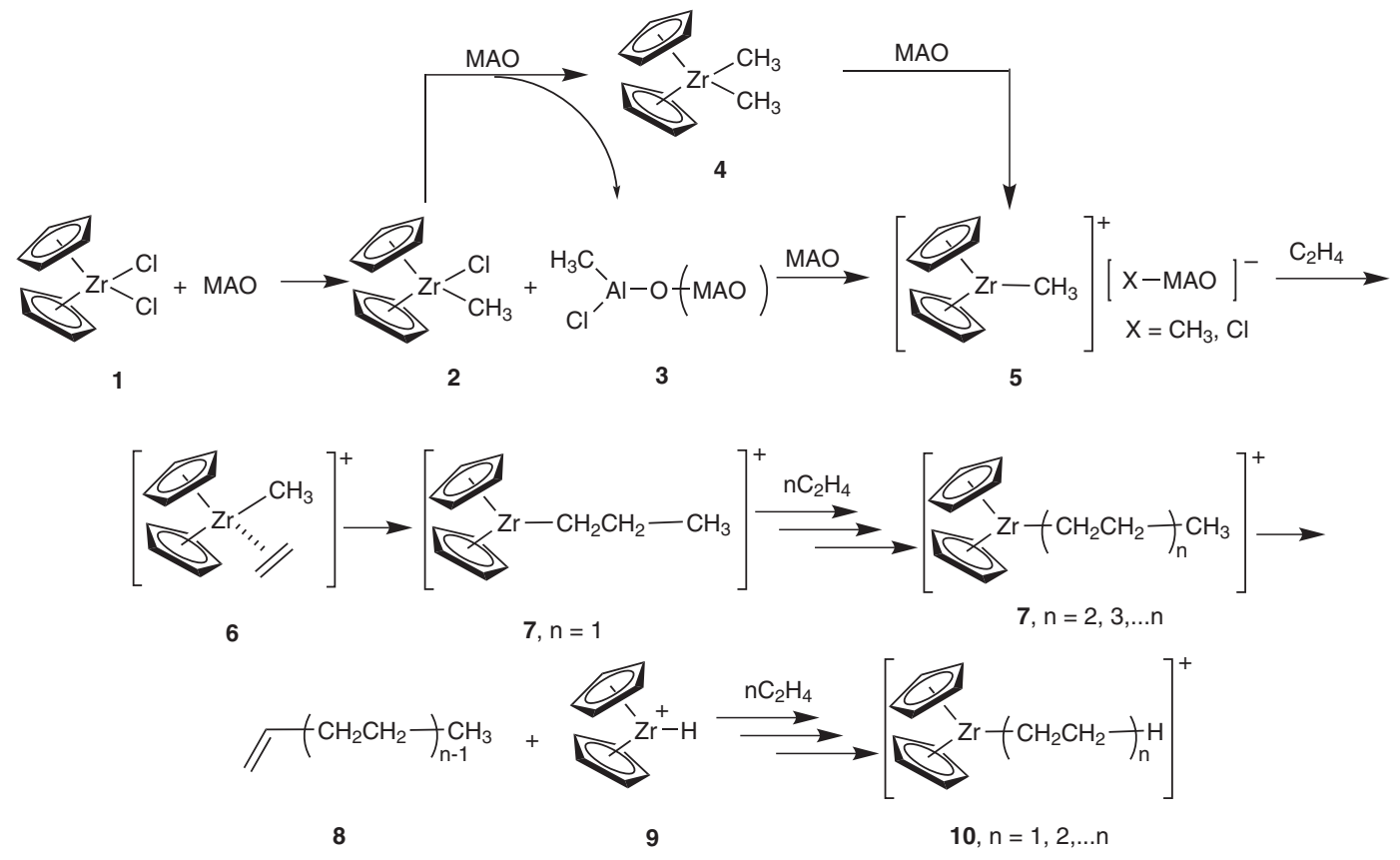

Scheme 13. Proposed mechanism of Ziegler-Natta polymerization of $\mathrm{C}_{2} \mathrm{H}_{4}$ using the homogenous catalyst $\mathrm{Cp}_{2} \mathrm{ZrCl}_{2} / \mathrm{MAO}$. 
intercept the intermediate alkyl zirconium cations of the growing polymer chain of the homogeneous ZieglerNatta polymerization of ethene directly from the solution, characterize them by mass spectrometry and prove directly their catalytic activity by gas phase reactions with ethene.

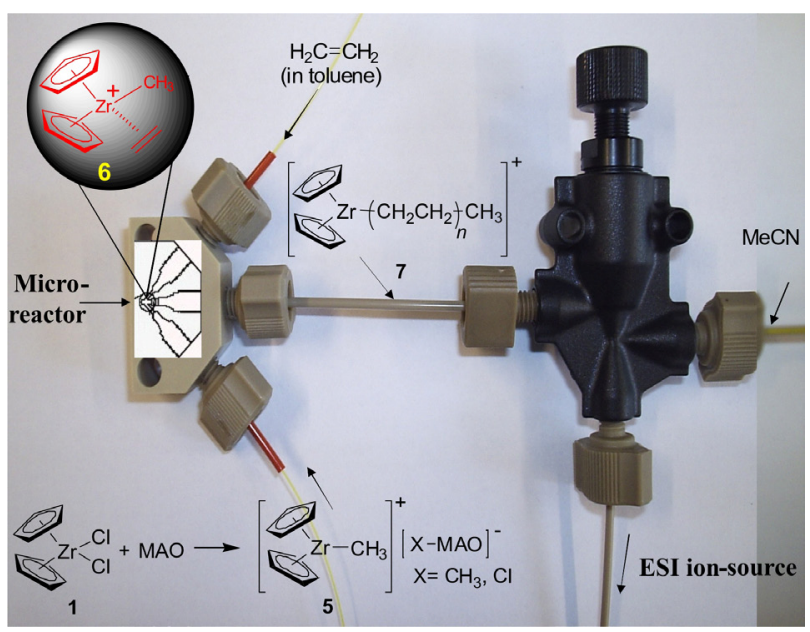

Figure 3. Microreactor coupled on-line to ESI source. In the first micromixer (left) toluene solutions of the preformed catalyst $\left[\mathrm{Cp}_{2} \mathrm{ZrCl}_{2}\right] / \mathrm{MAO}$ (1:1.2 equiv.) and of $\mathrm{C}_{2} \mathrm{H}_{4}$ were mixed continuously to initiate the polymerization. The reaction occurred in the capillary transferring the reacting solution to the second micromixer (right), where it is quenched by $\mathrm{MeCN}$ and from which it is fed directly to the ESI source. The overall reaction time was approximately $1.7 \mathrm{~s}$.

Thus, to probe directly that ion (5) is indeed the catalytically active species we studied the gas-phase reaction of the monoisotopic ion (5) of $\mathrm{m} / \mathrm{z}, 235$ (selected in the quadrupole) in the collision cell (T-wave) of the Q-TOF (quadrupole time-of-flight) with ethene and carried out mass analysis of the product ions using the TOF (time-of-flight) analyzer. Cation (5) reacted with $\mathrm{C}_{2} \mathrm{H}_{4}$ yielding the cationic addition product ions $(7)(n=1-4)$ in good yields (Figure 4a). Furthermore, all the ions (7) and (10) should be catalytically active that was proved directly by investigating their reaction with ethene in the gas phase. Ion (7) $(\mathrm{n}=1)$ of $\mathrm{m} / \mathrm{z} 263$ showed the addition of four units of ethene affording the product ions of $m / z 291,319$, 347 and 375 (Figure 4b). The ions (7) $(n=3,10,20)$ obtained in solution showed that these species are also reactive toward $\mathrm{C}_{2} \mathrm{H}_{4}$, as exemplified for ion $7(n=20)$ in Figure $4 c$. The even-numbered chain species $(\mathbf{1 0})(n=16)$ of $\mathrm{m} / \mathrm{z} 669$ was also reactive toward $\mathrm{C}_{2} \mathrm{H}_{4}$ showing two insertion products of $\mathrm{m} / z 697$ and 725 (Figure 4d).

\subsection{Brookhart polymerization}

Employing the same device described above, we described the study of Brookhart polymerization of ethene (Scheme 14) and of 1-butene with the homogeneous (a)

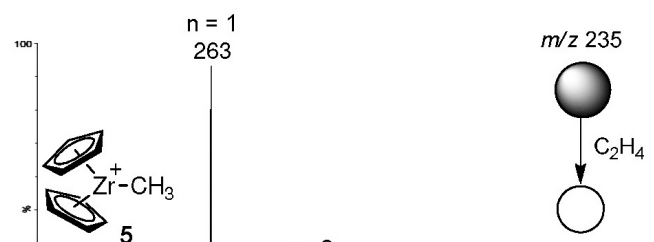

(b)

(c)
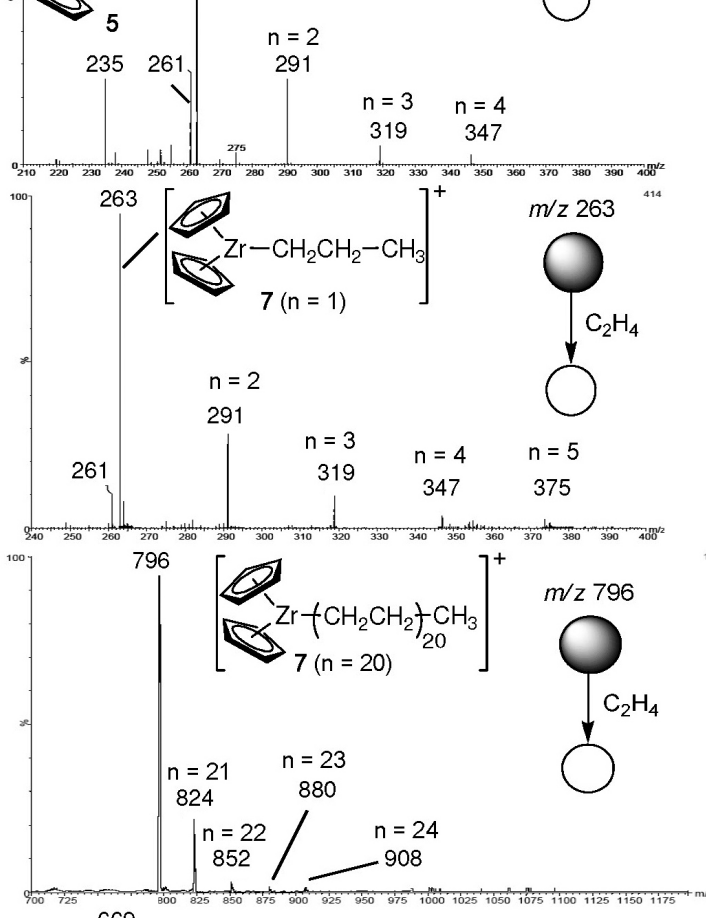

(d)

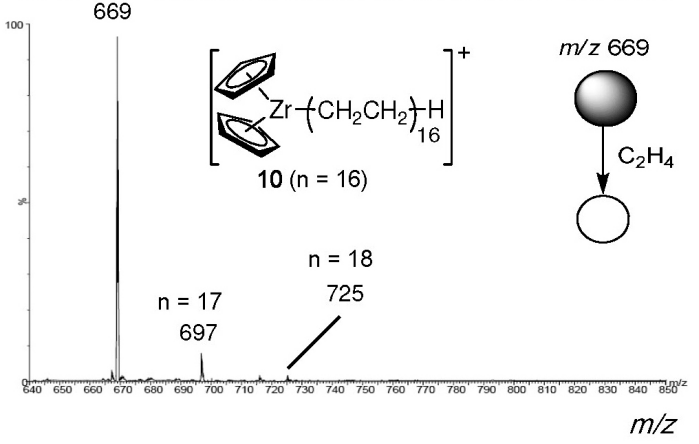

Figure 4. Proof of catalytic activity in the gas phase of zirconocene intermediates through MS/MS product-ion mass spectra for reactions of ethene with (a) 5, (b) $7(n=1)$, (c) $7(n=20)$ and (d) $10(n=16)$.

catalyst diimine $\mathrm{Pd}(\mathrm{Me}) \mathrm{Cl}$, with methylaluminoxane (MAO) or silver trifluoromethanesulfonate (AgOTf) as co-catalysts focusing on the direct detection and mass spectrometric characterization of the transient cationic and catalytically active species involved, and on the direct demonstration of their catalytic activity by ion/molecule reactions. ${ }^{49}$ Figure 5 shows the data collected by an electrospray ionization (ESI) mass spectrometer coupled online with a microreactor, which permitted the fast screening of polymerization growth of alkenes in the liquid phase mediated by palladium Brookhart catalyst and allowed the direct mass spectrometric identification of alkyl chains still bonded to Pd. 


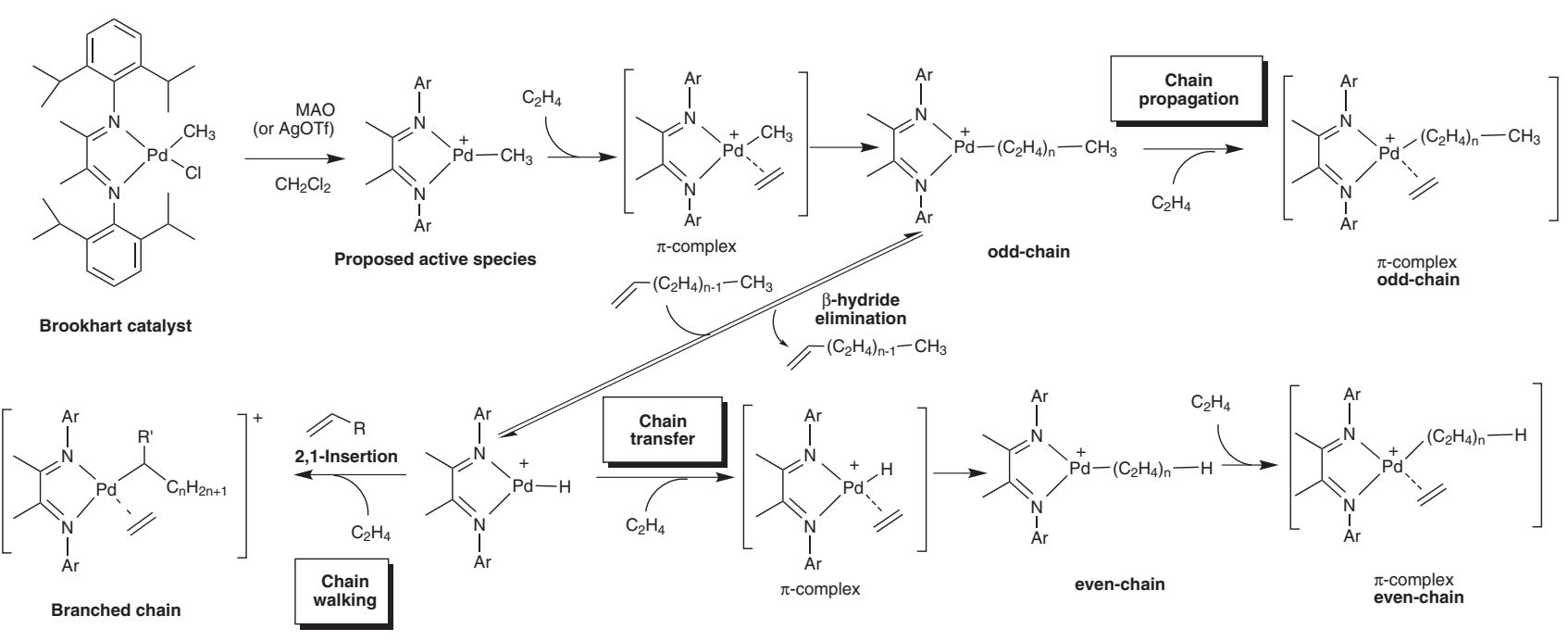

Scheme 14. Simplified mechanism for Brookhart polymerization of ethene using diimine-Pd(II) complex.

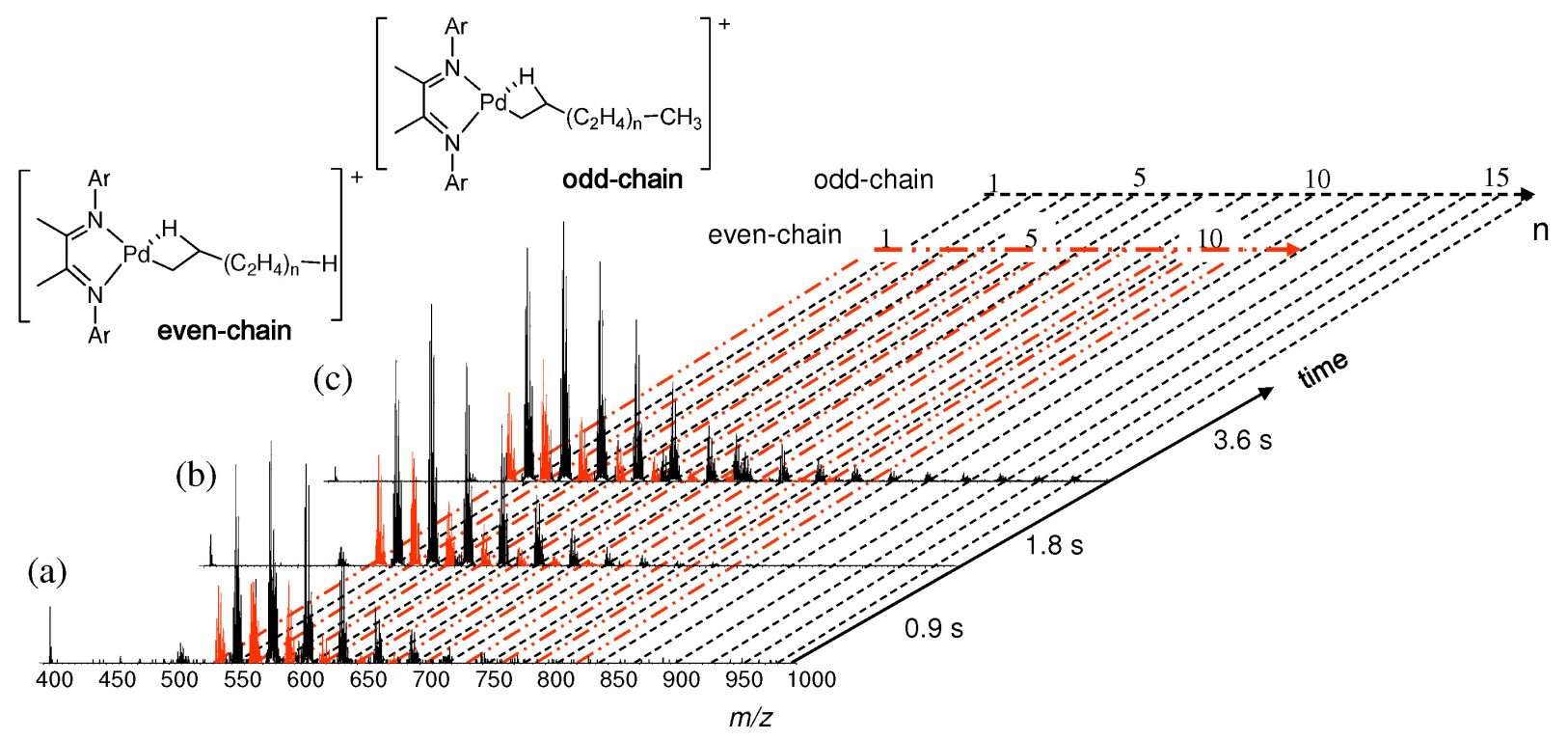

Figure 5. On-line ESI mass spectra of the reacting solution of ethene/pre-catalyst/MAO after reaction times of $0.9,1.8$ and $3.6 \mathrm{~s}$ showing higher intensity odd-chain and lower intensity even-chain product series using a microreactor.

\section{Conclusion and Prospects}

This technique have spurred other endeavors on organometallic catalysts as described recently in literature..$^{50,51}$ This account may serve to show the significant innovative potential of ESI-MS for the investigation of reaction mechanisms of organic and organometallic reagents in the gas phase. It is exemplified herein the usage of the ion/molecule reactions to probe the catalyst activity of different species intercepted in condensed phase, a straightforward method not available so far. Further developments of commercial available equipments are required for spread this powerful methodology worldwide.

\section{Acknowledgements}

L. S. S. thanks FONDECYT (1110022) and InnovaCorfo (FCR-CBS 09CEII-6991) for financial support.

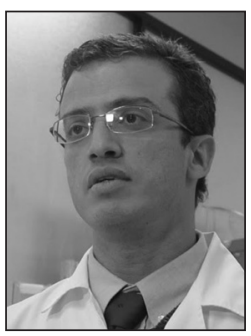

Prof. Dr. Leonardo S. Santos received his $P h D$ from University of Campinas (UNICAMP, São Paulo State, Brazil) in 2003, working under the direction of Prof. Dr. R. A. Pilli. Following his PhD, Leonardo took up a postdoctoral position at the Thomson Mass Spectrometry Laboratory at 
Unicamp, where alongside Prof. Dr. M. Eberlin he established ESI-MS-based mechanistic studies in Brazil. He spent some time working in the group of Prof. Dr. Jürgen O. Metzger at the Carl von Ossietzky University (Oldenburg, Germany) before moving to Chile in 2006. He is currently Full Professor at the Chemistry Institute of Natural Resources at Talca University (Talca, Chile) and established the Laboratories of Asymmetric Synthesis and Fraunhofer Nano. He is involved with the establishment of the Fraunhofer Institute in Chile and heads the chemistry group associated with the use of nanotechnology in agriculture and health. Professor Santos has published over 80 articles with more than 1500 citations, holds three international patents and received numerous international honors and awards (OPCW, Indian Society of Chemistry and Biology and others). Finally, his work in the field of mechanism of polymers and co-catalyzed reactions by mass spectrometry in solutions allowed him to publish his first book from Wiley-VCH, Weinheim, entitled "Reactive Intermediates - MS Investigations in Solution" in 2010.

\section{References}

1. Vorfalt, T.; Wannowius, K.-J.; Plenio, H.; Angew. Chem., Int. Ed. 2010, 49, 5533.

2. Santos, L. S.; Reactive Intermediates: MS Investigations in Solution; Wiley-VCH: Weinheim, 2010.

3. Santos, L. S.; Knaack, L.; Metzger, J. O.; Int. J. Mass Spectrom. 2005, 246, 84.

4. Chen, P.; Angew. Chem., Int. Ed. 2003, 42, 2832.

5. Fenn, J. B.; Mann, M.; Meng, C. K.; Wong, S. F.; Whitehouse, C. M.; Mass Spectrom. Rev. 1990, 9, 37.

6. Kebarle, P.; Tang, L.; Anal. Chem. 1993, 65, 972.

7. Gaskell, S. J.; J. Mass Spectrom. 1997, 32, 677.

8. Jones, J. L.; Dongre, A. R.; Somogyi, A.; Wysocki, V. H.; J. Am. Chem. Soc. 1994, 116, 8368.

9. Kebarle, P.; Ho, Y. In Electrospray Ionization Mass Spectrometry. On the Mechanism of Electrospray Ionization; Cole, R. B., ed.; Wiley: New York, 1997, pp. 3-63.

10. de la Mora, J. F.; Van Berckel, G. J.; Enke, C. G.; Cole, R. B.; Martinez-Sanchez, M.; Fenn, J. B.; J. Mass Spectrom. 2000, $35,939$.

11. Van Berkel, G. J. In Electrospray Ionization Mass Spectrometry. The Electrolytic Nature of Electrospray; Cole, R. B., ed.; Wiley: New York, 1997, p. 65-105.

12. Van Berkel, G. J.; Asano, K. G.; Gragner, M. C.; Anal. Chem. 2004, 76, 1493.

13. Schäfer, A.; Fischer, B.; Paul, H.; Bosshard, R.; Hesse, M.; Viscontini, M.; Helv. Chim. Acta 1992, 75, 1955.

14. Wilson, S. R.; Perez, J.; Pasternak, A.; J. Am. Chem. Soc. 1993, $115,1994$.
15. Aliprantis, A. O.; Canary, J. W.; J. Am. Chem. Soc. 1994, 116, 6985.

16. Moreno-Manas, M.; Perez, M.; Pleixats, R.; J. Org. Chem. 1996, $61,2346$.

17. Hambitzer, G.; Heitbaum, J.; Anal. Chem. 1986, 58, 1067.

18. Sam, J. W.; Tang, X. J.; Magliozzo, R. S.; Peisach, J.; J. Am. Chem. Soc. 1995, 117, 1012.

19. Meyer, S.; Koch, R.; Metzger, J. O.; Angew. Chem., Int. Ed. 2003, 42, 4700 .

20. Zhang, X.; Liao, Y. X.; Qian, R.; Wang, H. Y.; Guo, Y. L.; Org. Lett. 2005, 7, 3877.

21. Moura, F. C. C.; Araujo, M. H.; Dalmazio, I.; Alves, T. M. A.; Santos, L. S.; Eberlin, M. N.; Augusti, R.; Lago, R. M.; Rapid Commun. Mass Spectrom. 2006, 20, 1859.

22. Dalmazio, I.; Santos, L. S.; Lopes, R. P.; Eberlin, M. N.; Augusti, R.; Env. Sci. Technol. 2005, 39, 5982.

23. Claeys, M.; Graham, B.; Vas, G.; Wang, W.; Vermeylen, R.; Pashynska, V.; Cafmeyer, J.; Guyon, P.; Andreae, M. O.; Artaxo, P.; Maenhaut, W.; Science 2004, 303, 1173.

24. Santos, L. S.; Dalmazio, I.; Eberlin, M. N.; Claeys, M.; Augusti, R.; Rapid Commun. Mass Spectrom. 2006, 20, 2104.

25. Santos, L. S.; Pavam, C. H.; Almeida, W. P.; Coelho, F.; Eberlin, M. N.; Angew. Chem., Int. Ed. 2004, 43, 4330.

26. Cantillo, D.; Kappe, C. O.; J. Org. Chem. 2010, 75, 8615.

27. Santos, L. S.; Silveira Neto, B. A.; Consorti, C. S.; Pavam, C. H.; Almeida, W. P.; Coelho, F.; Dupont, J.; Eberlin, M. N.; J. Phys. Org. Chem. 2006, 19, 731.

28. Ferraz, H. M. C.; Pereira, F. L. C.; Goncalo, E. R. S.; Santos, L. S.; Eberlin, M. N.; J. Org. Chem. 2005, 70, 110.

29. Domingos, J. B.; Longhinotti, E.; Brandão, T. A. S.; Santos, L. S.; Eberlin, M. N.; Bunton, C. A.; Nome, F.; J. Org. Chem. 2004, 69, 7898.

30. Milagre, C. D. F.; Milagre, H. M. S.; Santos, L. S.; Lopes, M. L. A.; Rodrigues, J. A. R.; Moran, P. J. S.; Eberlin, M. N.; J. Mass Spectrom. 2007, 42, 1287.

31. Marquez, C. A.; Fabbretti, F.; Metzger, J. O.; Angew. Chem., Int. Ed. 2007, 46, 6915.

32. Zhang, X.; Guo, Y. L.; Rapid Commun. Mass Spectrom. 2006, $20,3477$.

33. Masllorens, J.; Moreno-Manãs, M.; Pla-Quintana, A.; Roglans, A.; Org. Lett. 2003, 5, 1559.

34. Moreno-Manãs, M.; Pleixats, R.; Sebastian, R. M.; Vallribera, A.; Roglans, A.; J. Organomet. Chem. 2004, 689, 3669.

35. Sabino, A. A.; Machado, A. H. L.; Correia, C. R. D.; Eberlin, M. N.; Angew. Chem., Int. Ed. 2004, 43, 2514.

36. Armendía, M. A.; Lafont, F.; Moreno-Manãs, M.; Pleixats, R.; Roglans, A.; J. Org. Chem. 1999, 64, 3592.

37. Markert, C.; Pfaltz, A.; Angew. Chem., Int. Ed. 2004, 43, 2498.

38. Chevrin, C.; Le Bras, J.; Hénin, F.; Muzart, J.; Pla-Quintana, A.; Roglans, A.; Pleixats, R.; Organometallics 2004, 23, 4796. 
39. Santos, L. S.; Rosso, G. B.; Pilli, R. A.; Eberlin, M. N.; J. Org. Chem. 2007, 72, 5809.

40. Raminelli, C.; Prechtl, M. H.G.; Santos, L. S.; Eberlin, M. N.; Comasseto, J. V.; Organometallics 2004, 23, 3990.

41. Santos, L. S.; Cunha, R. L. O. R.; Comasseto, J. V.; Eberlin, M. N.; Rapid Commun. Mass Spectrom. 2007, 21, 1479.

42. Cojocaru, M.; Elyashiv, I.; Albeck, M.; J. Mass Spectrom. 1997, 31,705 .

43. O‘Hair, R. A. J.; Chem. Commun. 2006, 1469.

44. Cooks, R. G.; Eberlin, M. N.; Zheng, X.; Chen, H.; Tao, W. A.; Chem. Rev. 2006, 106, 188.

45. Kaminsky, W.; Steiger, R.; Polyhedron 1988, 7, 2375.

46. Gassman, P. G.; Callstrom, M. R.; J. Am. Chem. Soc. 1987, 109, 7875 .
47. Sishta, C.; Hathorn, R. M.; Marks, T. J.; J. Am. Chem. Soc. 1992, 114, 1112.

48. Santos, L. S.; Metzger, J. O.; Angew. Chem., Int. Ed. 2006, 45, 977.

49. Santos, L. S.; Metzger, J. O.; Rapid Commun. Mass Spectrom. 2008, 22, 898.

50. Silva, B. V.; Violante, F. A.; Pinto, A. C.; Santos, L. S.; Rapid Commun. Mass Spectrom. 2011, 25, 423.

51. Roithova, J.; Schroder, D.; Chem. Rev. 2010, 110, 1170.

Submitted: May 27, 2011

Published online: July 21, 2011 